\title{
Successful Learners of Distance Education: A case study of IGNOU
}

\author{
Dr. Pravat Kumar Jena \\ Assistant Regional Director, \\ IGNOU Regional Centre, C-1, Institutional Area, Bhubaneswa-751013. \\ Email - pravat@ignou.ac.in
}

\begin{abstract}
Abstrac : Education is the basic requirement for human development. With education, employment opportunities are broadened and income levels are increased. The development of an individual and the progress of a nation depend on education. Open and Distance Learning $(O D L)$ is one of the most rapidly growing fields of education which facilitates open entry and access to learning opportunities, enhances the employability skills of the learner and makes them to achieve their goals in life. Though the student's enrollment in Higher Education through ODL system has increased, but the ODL institutions need to emphasize on student success rates. There are a number of factors that contribute toward better success rate. In this article one online survey was undertaken among successful learners of Indira Gandhi National Open University (IGNOU) through Google form with questionnaires on their success factors. Their views are analyzed and found some important factors which are required to enhance the success rates of ODL institutions. It is very interesting to note that majority of learners (44\%) developed their skills to do self-learning and $27 \%$ of learners developed an attitude of lifelong learning. $98 \%$ of successful learners acknowledged that the study material of IGNOU helped them greatly in earning their degrees. 95\% learners viewed in favour of assignment components which are very helpful for Term-End-Examinations.
\end{abstract}

Key Words: ODL system, Success factors, IGNOU

\section{INTRODUCTION:}

Education is the basic requirement for human development. With education, employment opportunities are broadened and income levels are increased. The development of an individual and the progress of a nation depend on education. The important strategy of any country in improving poverty is through the provision of education (Tilak, 2005). Once the majority of the poor receive education, they will be able to sustain themselves either through creating employment or finding employment in the job market. Most of the countries in the world prioritized the agenda to expand enrollments in Higher Education (HE) through aggressive policy changes. The United Nations (UN, 2015) aim to ensure inclusive and equitable quality education and promote lifelong learning opportunities for all, which is a global goal for 2030. Learning in HE is accessed through different modes including distance, full time, or part time. Open and distance education is flexible and student centered in approach. The Open and Distance Learning (ODL) system focuses on access to education by liberating learners from the constraints of time and place and offering flexible learning opportunities to all. ODL is one of the most rapidly growing fields of education which has been greatly highlighted through the development of internet-based information technologies. It facilitates open entry and access to learning opportunities, enhances the employability skills of the learner and makes them to achieve their goals in life. Distance education institutions play a vital role in providing higher education to all irrespective of their limitations imposed by social status or demographic constraints. ODL has grown exponentially over the past few years in the world. However credible research statistics on the students' success rates indicates a shocking and uncomfortable picture in the Higher Education sector throughout the world. The HE institutions are facing many challenges related to the success rates. Student success rate is understood and described differently by different scholars. Generally student success rate is the process in which students complete their qualifications and earn a degree successfully. As pointed by Bound J, Lovenheim MF \&Turner S. (2010), the pass percentage rate at HE, particularly in ODL, is alarming. In ODL settings, the institutions have a huge responsibility and are under pressure to ensure that better opportunities are created to boost the academic achievements of the students. Brock (2010) pointed that "although access to higher education has increased substantially over the past forty years, student success as measured by persistence and degree attainment, has not improved at all." Many credible research findings imply that though the students enrollment in HE through ODL system have increased, but the ODL institutions continue to face low student success rates because some of the enrolled students do not complete their qualifications within regulated specifications and some drop out of the system. What makes matters worse is the fact that ODL institutions do not only face low students' pass rates but the majority also drops out from the system. There are a number of factors that contribute toward low students' success rate. These factors may be like students' under preparedness, lack of guidance from counsellors or University, social causes etc. The focus of this article is to analyse the factors affecting the success rates of distance learners. To increase the success rate of distant learners the learner support services must be 
strengthened. Learners must get proper counseling on distance education system in order to minimize the dropout rates. Academic counselling services of IGNOU is an important activity of learner support services which resolves learners difficulties and generate a good spirit with confidence to achieve the goal (Pravat, 2018). Learners must also be guided about the assessment system followed by the distance education institution. The awareness on the assessment system of the institution will definitely have great impact on success rate of the learners. As we are taking a case study of IGNOU, the learners must be aware on the details of academic assessment system of IGNOU (Pravat, 2019) which plays a vital role on success rate. Issues pertaining to customer focused support should be given utmost importance and priority by distance education providers. A survey on the reasons responsible for student dropout from the BSc Programme at IGNOU by Bharat Inder Fozar, Lalit S. Kumar and S. Kannan (2006) also reveals that since the students are the major stake holders of ODL institutions, the institution should provide best services and student support to help them succeed.

\subsection{OBJECTIVE OF THE STUDY:}

The objective of the study is to:

- Analyze and understand the factors which played important role in earning their degree successfully in ODL system.

- Analyze the views/perceptions of successful learners and their advice for the future learners.

- Suggest corrective measures to improve success rates learner's in ODL system of IGNOU.

\subsection{SAMPLE SIZE AND METHODOLOGY OF THE STUDY:}

A study was conducted among IGNOU learners using a multipurpose questionnaire containing 15 items. The questionnaire was sent to the email addresses of successful learners of IGNOU Regional Centre, Bhubaneswar who earned their degrees in $32^{\text {nd }}$ convocations held during the year 2019 and their responses were collected through online Google form. Out of 1246 email addresses, 227 email addresses were found invalid and rest were delivered. Total of 119 learners submitted their responses through Google form which are analyzed in this article. An attempt has been made to understand the successful learners and to get the requisite information on their success factors. The perceptions/views of successful learners are collected and analyzed to study different success factors of distant learners of IGNOU and discussed the issues to enhance success rates.

\subsection{SIGNIFICANCE OF THE STUDY:}

- This study highlights the significant factors of successful learners which played important role in earning their degrees successfully in ODL system. Therefore, an idea about the strengths and weaknesses of success factors of distance learners can be taken by reviewing the study.

- The analysis and results of this study are useful to improve the success rates of distant learners in ODL system.

\section{FINDINGS OF THE STUDY:}

In order to understand the various factors that had facilitated the learners to successfully complete their study, total of 119 responses are received form learners of different programmes and analyzed as below: The level of academic programme completed by the respondents from IGNOU such as post graduation/graduation/post graduate diploma/diploma etc. is given in Table-1 and Chart-A.

Table-1

Level of academic qualifications of the respondents.

\begin{tabular}{|l|l|l|l|l|l|}
\hline $\begin{array}{l}\text { Master's } \\
\text { Degree } \\
\text { Progarmme } \\
\text { MDP) }\end{array}$ & $\begin{array}{l}\text { Bachelor's } \\
\text { Degree } \\
\text { Programme } \\
\text { (BDP) }\end{array}$ & $\begin{array}{l}\text { Management } \\
\text { Programme } \\
\text { (MP) }\end{array}$ & $\begin{array}{l}\text { Bachelor's of } \\
\text { Education (BEd) }\end{array}$ & P.G Dipolma & Diploma \\
\hline 28 & 61 & 9 & 14 & 7 & 0 \\
\hline
\end{tabular}

$51 \%$ of the respondents had successfully completed their bachelors' degree, $23 \%$ were masters' degree holders and 6\% were PG Diploma holders. Among two professional programmes of IGNOU, 14\% from BEd and $8 \%$ from Management Programmes had also earned their degrees. But, no responses from the Diploma programme holders were received.

The data of Male-Female respondents of the sample is shown in Chart B which shows higher percentage of Male than the Female respondents in this sample 
Chart A

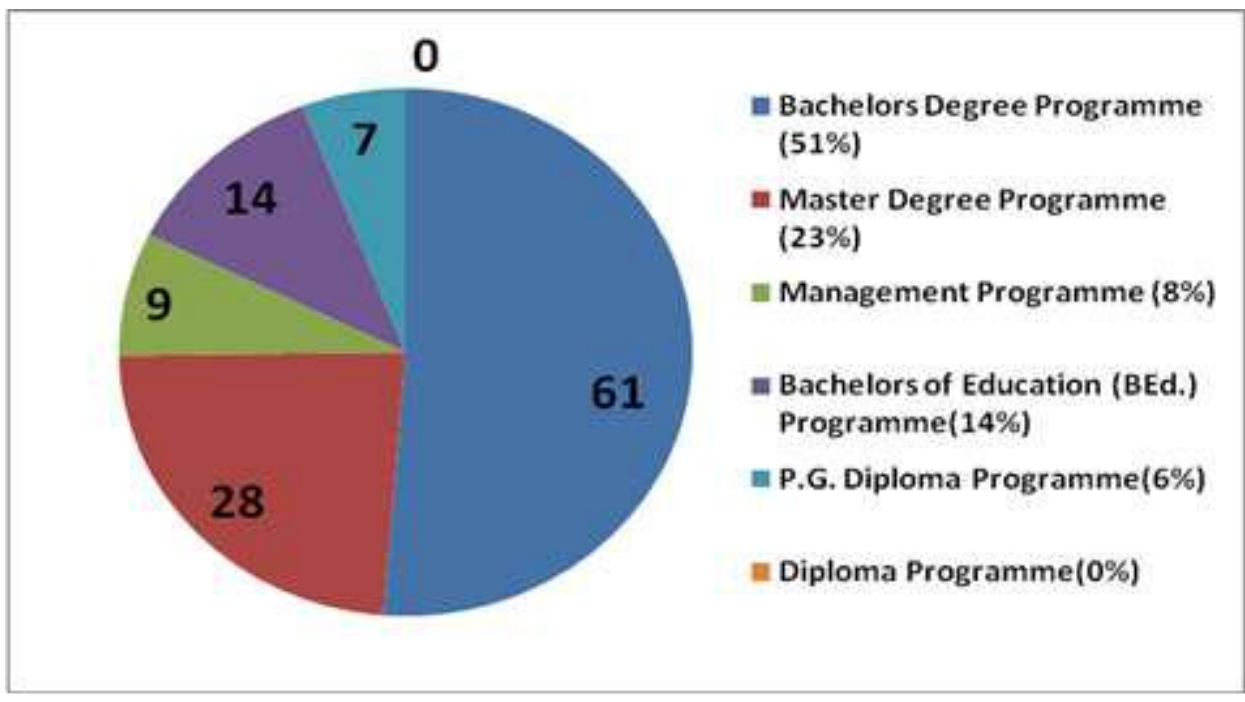

\section{Chart-B}

Male/Female respondents.

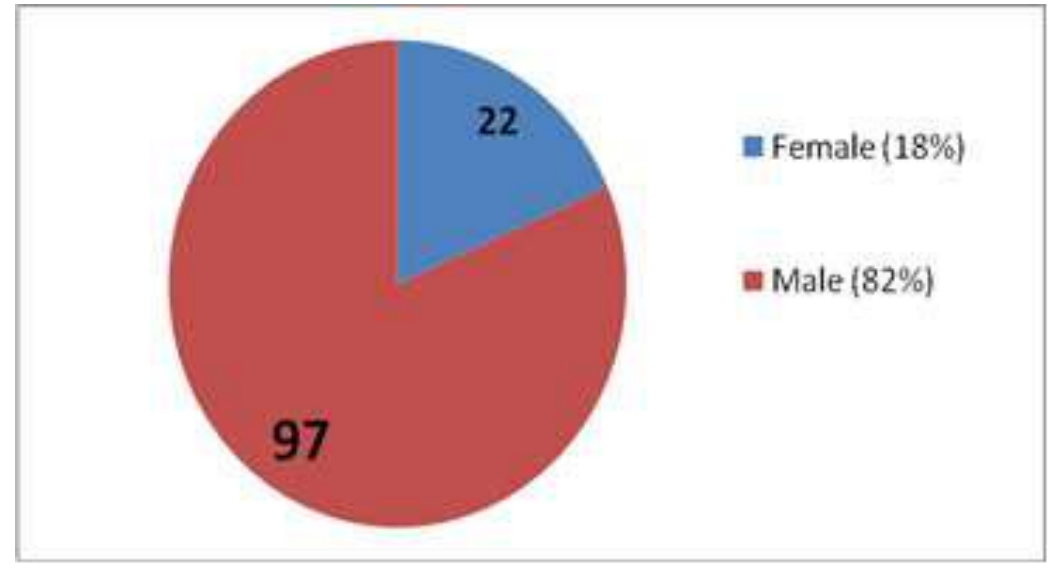

The data of rural/urban respondents of the sample is also shown in Chart-C which shows that more number of rural learners earned their degrees successfully than the urban learners. This indicates that more rural learners prefer distance mode of education.

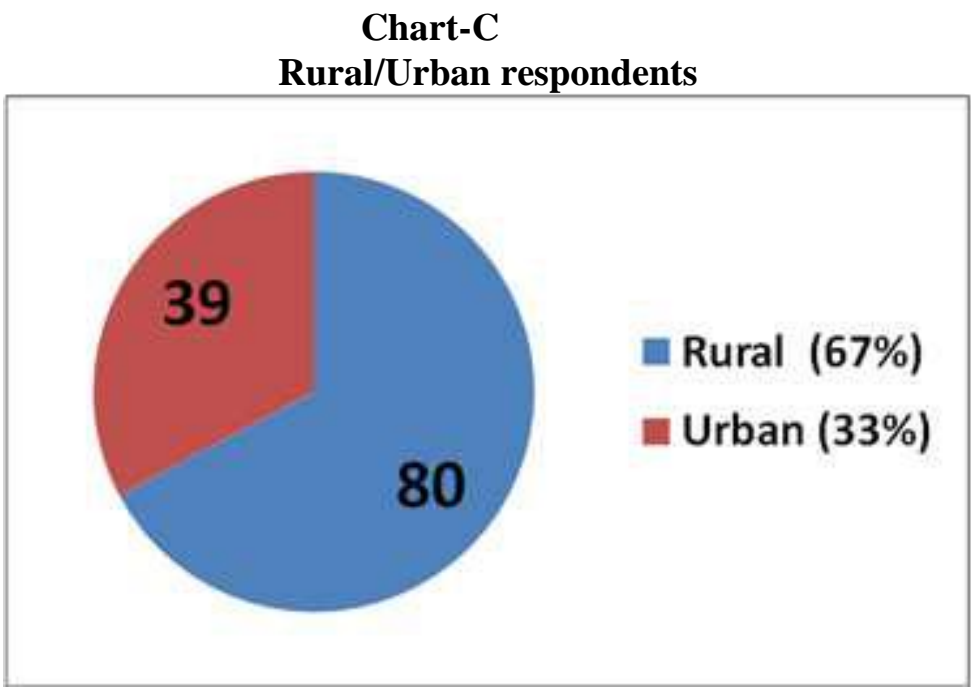

The social status of the successful learners like marital status, employment status and the categories they belong to are pointed in Table-2. 
Table-2

Social Status of the respondents

\begin{tabular}{|c|c|c|c|c|c|c|c|}
\hline \multicolumn{2}{|c|}{ Marital Status } & \multicolumn{4}{c|}{ Employment Status } & \multicolumn{4}{c|}{ Category } \\
\hline Married & Unmarried & Employed & Unemployed & SC & ST & OBC & General \\
\hline $52(44 \%)$ & $67(56 \%)$ & $96(81 \%)$ & $23(19 \%)$ & $14(12 \%)$ & $9(8 \%)$ & $42(35 \%)$ & $54(45 \%)$ \\
\hline
\end{tabular}

More numbers of employed persons and more numbers of unmarried respondents earned their degrees successfully. The pass out rate of SC/ST category students is very less in compare to the other categories. IGNOU should take proper steps to enhance the successes rate of SC/ST learners and motivate them thorough better counselling sessions. The overall experience as a learner with IGNOU is summarized in the below Table -3 and ChartD.

Table-3

\begin{tabular}{|l|l|}
\hline \multicolumn{2}{|c|}{ How was your overall experience with IGNOU? } \\
\hline \multicolumn{1}{|c|}{ Options } & \multicolumn{1}{c|}{$\begin{array}{c}\text { Frequency with percentage of } \\
\text { Respondents }\end{array}$} \\
\hline Pleasant & $65(55 \%)$ \\
\hline Satisfactory & $48(40 \%)$ \\
\hline Not satisfactory & $6(5 \%)$ \\
\hline
\end{tabular}

Chart-D

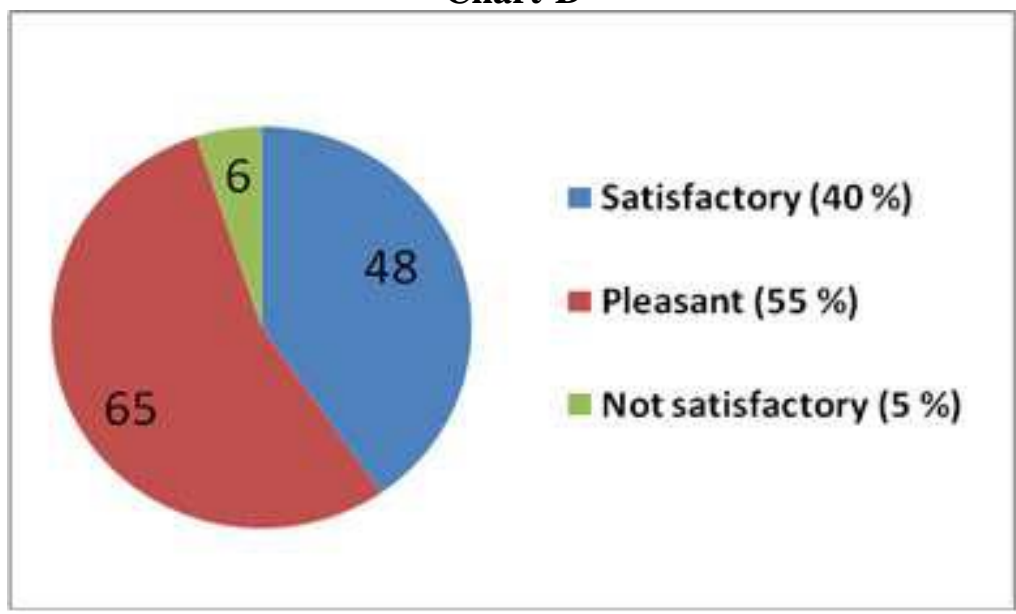

About $55 \%$ of the learners stated that they describe their ODL experience as very pleasant. Though the majority learners are positive about their experience, about $40 \%$ are just satisfied but about $5 \%$ did not have such an experience and are dissatisfied. Hence a learner friendly approach from functionaries at all levels of the Open University towards optimizing learner satisfaction would definitely encourage the learners to actively pursue their studies. Views on some important support services of IGNOU are collected and the frequency and percentage of respondents are placed in below tables.

Table-4

\begin{tabular}{|l|l|l|l|l|l|l|}
\hline \multicolumn{2}{|l|}{$\begin{array}{l}\text { Did you attend counseling sessions } \\
\text { of IGNOU }\end{array}$} & \multicolumn{2}{l|}{$\begin{array}{l}\text { Are assignments } \\
\text { helpful for Term-End- } \\
\text { Examinations of } \\
\text { IGNOU }\end{array}$} & $\begin{array}{l}\text { Are the Study } \\
\text { materials helped you } \\
\text { greatly to get success } \\
\text { in IGNOU }\end{array}$ \\
\hline Yes & No & $\begin{array}{l}\text { Some } \\
\text { classes }\end{array}$ & Yes & No & Yes & No \\
\hline 49 & 47 & 23 & 113 & 6 & 116 & 3 \\
\hline $41 \%$ & $40 \%$ & $19 \%$ & $95 \%$ & $5 \%$ & $98 \%$ & $2 \%$ \\
\hline
\end{tabular}

In IGNOU, attendance in counseling classes is not compulsory for most of the programmes except some practical based programmes. However, counseling classes are very useful for the learners to complete the progarmme successfully. It is a pleasure to note here that about $41 \%$ of the successful learners had attended counseling classes. 95\% learners viewed in favour of assignment components which are very helpful for Term-End-Examinations. IGNOU has become a famous University due to the quality of its study material and the same is also observed in this 
sample. $98 \%$ of successful learners acknowledged that the study material of IGNOU helped them greatly in earning their degrees. The learners were asked to choose any one of the factors from Table- 5 which helped them to complete the programme successfully. The frequency with percentage of the respondents is presented in the below Table-5.

Table-5

\begin{tabular}{|l|l|l|}
\hline \multicolumn{2}{|c|}{ What factors helped you to complete the programme successfully? } \\
\hline \multicolumn{2}{|c|}{ Factors } & \multicolumn{1}{|c|}{$\begin{array}{c}\text { Frequency with percentage of } \\
\text { Respondents }\end{array}$} \\
\hline I & $\begin{array}{l}\text { Study materials supplied by IGNOU facilitated greatly for } \\
\text { self learning }\end{array}$ & $60,(51 \%)$ \\
\hline II & Hard work with own efforts & $41,(34 \%)$ \\
\hline III & Due to information and response received from IGNOU & $7,(6 \%)$ \\
\hline IV & $\begin{array}{l}\text { Attending the multi-media programmes such as } \\
\text { teleconferencing Sessions/radio programmes etc. helped the } \\
\text { study }\end{array}$ & $4,(3 \%)$ \\
\hline V & Due to support of family/friends/peers & $7,(6 \%)$ \\
\hline
\end{tabular}

Out of all the above mentioned factors, majority of learners are recognizing their success factor as the study materials and their own efforts. $51 \%$ of learners have expressed their satisfaction on the study material supplied by IGNOU which facilitated them for success and 34\% of learners attributed their success on their hard work with own efforts. This indicates that a successful distant learner is always self dependent. The views of the learners on the types of Skills/qualities/abilities acquired by him as a successful distant learner are listed in Table-6.

Table-6

\begin{tabular}{|l|l|l|}
\hline \multicolumn{2}{|c|}{ Types of Skills/qualities/abilities acquired by you as a distant learner? } \\
\hline \multicolumn{2}{|c|}{ Types } & \multicolumn{1}{|c|}{$\begin{array}{c}\text { Frequency with percentage of } \\
\text { Respondents }\end{array}$} \\
\hline I & $\begin{array}{l}\text { Skill to do self-learning by sourcing reference material from } \\
\text { different sources like books/libraries/web }\end{array}$ & $52,(44 \%)$ \\
\hline II & Able to handle multiple roles simultaneously & $11,(9 \%)$ \\
\hline III & Developed time management skills & $6,(5 \%)$ \\
\hline IV & Developed an attitude of lifelong learning & $32,(27 \%)$ \\
\hline V & Developed self reading habits & $7,(6 \%)$ \\
\hline VI & Developed better writing skills & $11,(9 \%)$ \\
\hline
\end{tabular}

It is very interesting to note that majority of learners (44\%) developed their skills to do self-learning and $27 \%$ of learners developed an attitude of lifelong learning. Some learners have also developed their time management skill, better reading/writing skill and able to handle multiple role simultaneously. Reasons/occasions which demotivated /delayed the progress of study was collected from the successful distant learners and their frequency with percentage of respondents is listed in Table-7.

Table-7

\begin{tabular}{|c|c|c|}
\hline \multicolumn{3}{|c|}{ What are the reasons/occasions which demotivated/delayed your progress of study? } \\
\hline & Reasons & Frequency with percentage of \\
\hline I & $\begin{array}{l}\text { Job pressure/family responsibilities slowed down the } \\
\text { academic progress }\end{array}$ & $62,(52 \%)$ \\
\hline II & $\begin{array}{l}\text { There was delay in updating assignment grades in grade } \\
\text { card/delay in declaring Term-End Examination result }\end{array}$ & $14,(12 \%)$ \\
\hline III & $\begin{array}{l}\text { Could not get up-to-date information from SC } \\
\text { functionaries/RC }\end{array}$ & $7,(6 \%)$ \\
\hline IV & $\begin{array}{l}\text { Study centre for the programme is far away from my } \\
\text { residence }\end{array}$ & $15,(13 \%)$ \\
\hline $\mathrm{V}$ & Sometimes counsellors are unable to clear the doubts & $2,(1 \%)$ \\
\hline VI & Delay in getting response/reply of queries from IGNOU & $19,(16 \%)$ \\
\hline
\end{tabular}

Majority of the learners (52\%) are citing the reason of their delay in progress as job/family responsibility which is a personal reason and the University can't do anything for this. 16\% of learners are not getting proper reply 
of their queries, $12 \%$ learners are complaining about delay in updation of result in grade cards etc. That means a total of $48 \%$ of these successful learners are citing the delay in academic progress as the deficiency in support services (Reasons-II to VI) of IGNOU. Therefore, in open education system, the institution (IGNOU) should strengthen the learner support system to increase the pass out rates in different programmes. The advice of the successful learners to a new learner to complete his/her study successfully is presented in Table- 8 .

Table-8

\begin{tabular}{|l|l|l|}
\hline \multicolumn{2}{|c|}{ As a successful learner, what is your advice to a new learner to successfully complete his/her study? } \\
\hline \multicolumn{2}{|c|}{ Types } & $\begin{array}{c}\text { Frequency with percentage of } \\
\text { Respondents }\end{array}$ \\
\hline I & Read and understand Self-instructional materials thoroughly. & $38,(32 \%)$ \\
\hline II & $\begin{array}{l}\text { Collect time to time necessary information from IGNOU } \\
\text { website. }\end{array}$ & $6,(5 \%)$ \\
\hline III & $\begin{array}{l}\text { Prepare and write your assignments sincerely which will be } \\
\text { great help for Term-End Examination. }\end{array}$ & $48,(41 \%)$ \\
\hline IV & Try to complete your programme within minimum duration & $23,(19 \%)$ \\
\hline V & The academic calendar should be followed systematically & $4,(3 \%)$ \\
\hline
\end{tabular}

$41 \%$ of the successful distant learners are advising the new learner to prepare and write the assignments sincerely which would be great help for Term-End Examination. The second most important advice by $32 \%$ learners is to read and understand Self-instructional materials. 19\% learners are also advising to complete your programme within minimum duration and 5\% are suggesting keep themselves updated on necessary information from IGNOU website. One option was also given to the learners to write anything else that they would like to mention and their points were as below:

- Some learners had mentioned that IGNOU is providing excellent material but the learner support services are not upto the mark.

- The official website of IGNOU is also having very bad response sometimes.

- Some of them suggested IGNOU to start Master Degree programmes in Basic Science subjects as well as Nursing programmes.

- Most of the learners are also complaining on non-receipt on Study materials in time

\section{DISCUSSION \& CONCLUSION:}

- This study reveals that majority (81\%) of employed learners have earned their degrees successfully from IGNOU though they get less time to devote for study.

- The pass out rate of SC/ST category students is very less in compare to the other categories. Therefore, IGNOU should take proper steps to enhance the successes rate of SC/ST learners and motivate them thorough better counselling sessions.

- About 55\% of the learners stated that they describe their Open University experience as very pleasant. Though the majority of learners are positive about their experience, about $40 \%$ are just satisfied but about $5 \%$ did not have such an experience and are dissatisfied. Hence a learner friendly approach from functionaries at all levels of the Open University towards optimizing learner satisfaction would definitely encourage the learners to actively pursue their studies.

- It has also been observed that more numbers of rural learners earned their degrees successfully than the urban learners which indicate that distance mode of education is more effective in rural areas.

- $95 \%$ learners viewed in favour of assignment components which are very helpful for Term-EndExaminations. Hence, IGNOU should motivate/guide the learners through counseling classes on how to deal with the assignment components successfully.

- IGNOU has become a famous University due to the quality of its study material and the same is also observed in this survey. $98 \%$ of successful learners acknowledged that the study material of IGNOU helped them greatly in earning their degrees.

- It is very interesting to note that majority of learners (44\%) developed their skills to do self-learning and $27 \%$ of learners developed an attitude of lifelong learning. Some learners have also developed their time management skill, better reading/writing skill and able to handle multiple role simultaneously.

- Majority of the learners (52\%) are citing the reason of their delay in progress due to personal reason but a total of $48 \%$ of these successful learners are blaming IGNOU for deficiency in support services. Therefore, in open education system, the institution (IGNOU) should strengthen the learner support system to increase the pass out rates in different programmes. 
As we all know that increasing student retention in distance education system is a matter of great concern for every open education system. In general, a good customer service means attracting the customers towards the product/services and trying to retain all customers to take all benefit from the full product. So, the distance education institutions should strengthen their student support services system to increase their student success rate as well as the student retention rate. From the above statements of the paper it is clear that there should be an induction programme on ODL support services system of IGNOU. All the counselors and Study centre functionaries should be oriented on all the activities of the University and be trained on how to deal with the learners for better support services. The results indicated some areas in which further research would be useful for better success rate and some areas where the university needs to evaluate its performance in relation to students' expectations.

\section{REFERENCES:}

1. Tilak, J.B.G.(2005). Post Elementary Education, Poverty and Development in India. International Journal of Educational Development, 27, 435-445

2. UN (2015), Transforming Our World: The 2030 Agenda for Sustainable Development, 2015. Source: https://www.un.org/en/development/desa/population/migration/generalassembly/docs/globalcompact/A_RES_ 70_1_E.pdf

3. Bound J, Lovenheim MF, Turner S. (2010): "Why have college completion rates declined? An analysis of changing student preparation and collegiate resources", American Economic Journal: Applied Economics, 2(3), 129-157.

4. Brock T. (2010): "Young adults and higher education: Barriers and breakthroughs to success", The Future of Children, 20(1), 109-132.

5. Pravat Ku. Jena (2018): “Academic Counselling Services in IGNOU, International Journal of Advanced Research, 6(4), 441-448.

6. Pravat Ku. Jena (2019): Academic Assessment System of Learners in IGNOU, International Journal of Advanced Research, 7(5), 381-389.

7. Bharat Inder Fozar, Lalit S. Kumar and S. Kannan (2006): "Survey of a study on the reasons responsible for student dropout from the BSc Programme at IGNOU", International Review of Research in Open and Distance Learning, 7(3). 